\title{
Legislative enforcement affecting construction site safety in Malaysia
}

\author{
Rozanah Ab. Rahman*
}

Faculty of Economics and Management, Universiti Putra Malaysia, 43400 UPM Serdang, Selangor, Malaysia

\section{A R T I C LE IN F O}

\section{Article history:}

Received 5 September 2016

Received in revised form

26 October 2016

Accepted 11 November 2016

Keywords:

Construction

Site safety

Investigation and enforcement

Regulatory impact assessment

\begin{abstract}
A B S T R A C T
Construction industry is compelled to comply with the Occupational Safety and Health Act (OSHA) 1994 and its Regulations made thereunder and the legislation laid down the duty holders' duties for the contractors and the subcontractors to ensure safety compliance at the project sites. The duty holders must take ownership of the outcome of the safety and health initiatives shouldered by them, including the contractual liability agreed upon in their contracts sealed for construction projects. In enforcing the OSHA 1994, the Department of Occupational Safety and Health (DOSH) is the enforcement authority given the power under the Act to carry out inspection and investigation upon occurrence of incidents at the workplaces. An important question raised by this paper focus on the enforcement and investigation of safety matters at the construction sites upon the amendment made to the CIDB Act 1994 that empowered CIDB to function into enforcement activities, disciplinary actions, prosecution action and penalty charges. The similar power of DOSH conferred on CIDB under the amended provisions would lead to duplication or overlapping instead of complementarity in nature and hence coordinated strategies and programs are obviously needed to overcome conflicts or disagreements and inconsistencies in managing the enforcement.
\end{abstract}

(C) 2016 The Authors. Published by IASE. This is an open access article under the CC BY-NC-ND license (http://creativecommons.org/licenses/by-nc-nd/4.0/).

\section{Introduction}

Since 1994, the Occupational Safety and Health Act (OSHA 1994) was enforced to govern the occupational safety and health issues at work in all industries except armed forces and work on boards' ships; and the statute imposed important duties on the duty holders, including employers, employees, designers, suppliers and manufacturers. These duties aim to protect workers' safety, health and welfare at work and there are legal sanctions in a form of fine, imprisonment or both for any violation of the legal duties under the OSHA 1994. As far as construction industry is concerned, once the contractor obtains the site possession from the employer, his obligations to safety and health requirements as demanded by the Act begin. The standard forms of agreement or construction contracts prepared for the sector, entered into by the employer and the contractor also provides for the need to observe safety clauses stipulated in the

\footnotetext{
* Corresponding Author.

Email Address:rozanah@upm.my (A. R. Rozanah)

https://doi.org/10.21833/ijaas.2016.11.016

2313-626X/C 2016 The Authors. Published by IASE.

This is an open access article under the CC BY-NC-ND license

(http://creativecommons.org/licenses/by-nc-nd/4.0/)
}

contracts as important requirements for their workers safety issues at sites.

\section{Statutory duties under the OSH legislation}

The contractor and the sub-contractors are mainly the duty holders to ensure compliance at the project sites. There are also obligations of competent persons at sites, i.e. the site safety supervisor and safety and health officer, for total project cost of 20 million and above.

Construction is one of the industries that are compelled to comply with the OSHA 1994 and its Regulations made thereunder. The term 'employer' under the Act covers immediate employer or principal employer or both (s.3). A "principal employer" means the owner of an industry or the person with whom an employee has entered into a contract of service and includes:

a) a manager, agent or person responsible for the payment of salary or wages to an employee;

b) the occupier of a place of work;

c) the legal representative of a deceased owner or occupier; and

d) any government in Malaysia, department of any such government, local authority or statutory body. 
An "immediate employer", in relation to employees employed by or through him, means a person who has undertaken the execution at the place of work where the principal employer is carrying on his trade, business, profession, vocation, occupation or calling, or under the supervision of the principal employer or his agent, of the whole or any part of any work which is ordinarily part of the work of the trade, business, profession, vocation, occupation or calling of the principal employer or is preliminary to the work carried on in, or incidental to the purpose of, any such trade, business, profession, vocation, occupation or calling, and includes a person by whom the services of an employee who has entered into a contract of service with him are temporarily lent or let on hire to the principal employer.

From the definition, employer in construction industry shall include client/owner of project or employer, contractor, sub-contractor, and occupier of the construction site. Hence, the employer has to generally manage the safety and health aspects of all his employees (including independent contractors engaged by an employer) in accordance with the following specific duties provided under section 15 of the OSHA 1994:

a) to provide and maintain plant and systems of work that are safe and without risks to health;

b) to make arrangements for ensuring safety and absence of risks to health in connection with the use or operation, handling, storage and transport of plant and substances;

c) to provide such information, instruction, training and supervision as is necessary to ensure the safety and health at work of his employees;

d) to provide and maintain means of access to and egress from, that are safe and without such risks, as regards any place of work under the control of the employer, and to maintain it in a condition that is safe and without risks to health;

e) to provide and maintain a working environment for his employees that is safe, without risks to health, and adequate as regards facilities for their welfare at work.

Obviously, the duty holders must take ownership of the outcome of the safety and health initiatives shouldered by them, including the contractual liability agreed upon in their contracts sealed for construction projects. All the above general duties are qualified by the phrase 'so far as is practicable' which means the employers shall carry out their duties practicably, having regards to (a) the severity of the hazard or risk in question; (b) the state of knowledge about the hazard or risk and any way of removing or mitigating the hazard or risk; (c) the availability and suitability of ways to remove or mitigate the hazard or risk; and (d) the cost of removing or mitigating the hazard or risk (section 3, OSHA 1994). Failure to comply with the above duties would make the employer liable for a fine not exceeding RM50,000 or to imprisonment not exceeding 2 years or both (section 19, OSHA 1994).

\section{Regulatory burden}

In enforcing the OSHA 1994, the Department of Occupational Safety and Health (DOSH), Ministry of Human Resources Malaysia is the enforcement authority given the power under the Act to enter work premise, carry out inspection and examine place of work, including taking samples and other evidences for purpose of investigation and further prosecution. Obviously, the aim of enforcement including prosecution is to ensure compliance with the law and to hold the duty holders under the Act accountable for failures to safeguard safety and health at the workplace. The idea of preventing harm shall be the ultimate purpose and ensuring that the risks are managed and controlled effectively by the duty holders.

Previous research conducted on the adequacy and inadequacy of the present safety at work legislation for construction sectors had made important recommendation to expedite the formulation of specific and new sets of Regulations for construction under the OSHA 1994, to cater for the prevalent and alarming safety and health issues in the industry. These proposed updated Regulations would cater not only the use of technology advances in construction to replace its outdated and obsolete version, but to enforce compliance to the Regulations through the concept of duty holders (Rozanah, 2015). Eventually, the whole initiatives should central around managing safety and health at the workplace through prevention of accident and reducing risk, and the duty holders must take ownership of the outcome of the safety and health initiatives.

The Occupational Safety and Health Master Plan (OSHMP) 2020 of Malaysia which focuses on preventive culture is aimed to increase quality of working lives, enhancing organizational productivity and competitiveness, and raising OSH awareness and welfare. In realizing the aim of the OSHMP, effective enforcement by the authority shall be part of the important activities to ensure legislative compliance. Credible criminal deterrence and successful convictions should deter the offenders and ensures greater compliance with the safety laws (Uhlmann, 2008), and effective structure of OSH legal enforcement is vital towards the aim of legal compliance and ensuring workers safety are protected. The minimum requirement for sanctions in law is that they must be adequate to serve as deterrence (OECD, 2013).

Therefore, in heading towards better regulatory practice, the government must continue to strengthen regulatory review initiatives to modernize the business environment in order to ensure that our competitiveness is further enhanced and sustained. The initiatives are vital to attain the confidence and trust of citizens, consumers and businesses on the Government machinery and its institutions. Malaysia realizes that it must introduce a regulatory framework that is more systematic to reduce regulatory burden on the economy and 
businesses, as highlighted in the Tenth Malaysia Plan that regulatory environment substantially affect companies' behavior and performance.

In pursuant to this, the National Policy on the Development and Implementation of Regulations requires all Federal Government regulators to undertake the Regulatory Impact Assessment (RIA) in creating all new regulations or review of regulations that relate to, or impact business, investments and trade, upon assessment by the Malaysia Productivity Corporation (MPC). MPC is entrusted with the task of designing the regulatory burden reduction plan and to continuously follow up on the effective implementation of regulatory reform initiatives.

RIA involves Impact Analysis whereby CostBenefit Analysis is used that emphasizes on the calculation of business impact assessment in terms of administrative burdens, license simplification, compliance costs on business, bearing capacity of SMEs, impacts on competition and social economic effects. Hence, measuring unnecessary compliance burdens imposed by the regulatory activities of government remains a challenge and the impacts of compliance burden can be substantial. If Malaysia can achieve $25 \%$ reduction target like many countries are doing, then unnecessary regulatory costs on the economy could result in savings for approximately RM4 billion. Having good regulatory practice by removing unnecessary regulatory burden that impact business innovation and effectiveness will ensure that Malaysia is on the right track to achieving high-income economy status (MPC, 2011).

Removal of regulations is important while the government help the industry to improve productivity and competitiveness. In country like Australia, the aim is to design best practice regulations that are less burdensome and to identify reforms through working closely with industry. Thus, any system, service or product, which had been approved under a reputable international standard, then no additional requirements for approval by the regulators, should be imposed. This effort led to the removal of regulatory duplication, reduction in costs and delays for business and consumers, and as an effect, it increases the supply of products into the market. The Australian Government aims to achieve reduction in duplicative processes across jurisdictions.

\section{OSH enforcement and investigation: Clash or complement}

Having elucidated the process of examining the likely impacts of proposed laws and regulations through RIA above, matter regarding the need to have specific and new sets of Regulations for construction activities under the OSHA 1994 of Malaysia is timely. While the industry and the enforcer foresee the need for these new Regulations to be expedited to replace the obsolete regulations (i.e. BOWECS Regulations under the FMA 1967), the government had also amended the Construction
Industry Development Board Act 1994 (Act 520). On July 12, 2012, the CIDB (Amendment) Act 2011 (Act A1407) was passed in Parliament and gazetted on September 15 the same year.

Looking at the Amendment Act 2011, CIDB is entrusted through the amendments to play it role as a regulatory body on matters relating to levy collection, registration and accreditation of contractors and construction personnel, conformance of standards for construction workmanship and materials, implementation for quality and safe construction works, implementation of Industrialized Building System in construction industry, and all other matters expedient or reasonably necessary for the performance of its functions. It is thus enhancing CIDB's function into enforcement activities, disciplinary actions, prosecution action and penalty charges against the violators.

As far as safety matters are concerned, the Amendment 2011 added CIDB's functions specifically to regulate the implementation for quality and safe construction works and to attend to any complaint or report made in relation to any failure of construction works or completed construction works, which affects public safety and take appropriate actions to address it.

However, among the major amendments that can be seen in the CIDB Act is the Enforcement and Investigation part in Part IX of the Amendment Act 2011. The provisions in Part IX has given CIDB similar power to DOSH under the OSHA 1994.

Whether the effect of enforcement power created under the amended provisions would really complement the existing enforcement power vested in DOSH is yet to be seen. Or is it in duplication or overlapping and thus it clashes rather than becomes complementarity in nature? Whether there is regulatory conflict and overlap when more than one entity shares authority over the same functional area? The elucidation to the above question is worth stressing as follows:

\subsection{Power of entry, inspection, examination, seizure by DOSH}

As far as the enforcement under the OSHA 1994 is concerned, the power is conferred on DOSH as the authority who shall at any reasonable time enter, inspect and examine any workplace, and in exercising such power, the officer may carry out the following functions:

a) Examine and investigate any plant, substance, article or other things to ascertain compliance to the Act and Regulations;

b) Direct the workplace, or any part of it, or anything therein, to be left undisturbed, for purpose of examination or investigation;

c) Take measurements and photographs and make recordings for purpose of examination or investigation; 
d) Take samples of articles or substance found in the workplace and take samples of the atmosphere in the workplace;

e) Require employees working in the workplace where the occupational disease has occurred or is likely to occur, to be medically examined by a medical officer or registered medical practitioner.

In a situation where the officer is of the opinion that a plant or substance has caused or is likely to cause a danger to safety and health, he may cause it to be dismantled or put it to any process or test; and take possession of it and detain it for the purpose of examining it, ensuring it is not tampered with before examination completed, and ensuring it is available for use as evidence in court proceedings.

If the officer is a medical officer, he may carry out medical examination and exercise other power as necessary. Officers of DOSH may also seek police assistance if there is serious obstruction in the performance of his duty. On entering the workplace, the officer may bring with him other person authorized by the Director General or any equipment or material required by him (s.39, OSHA 1994).

Under the CIDB Amendment Act, similar provision can be found permitting an authorized officer to enter premise or construction site to:

a) Inspect construction material, equipment, instrument, book, record, document, computerized document, article or other thing if necessary;

b) Verify accuracy of records or information statements given to Lembaga; and

c) Collect samples (s.35H).

The Act also allows search be made on person (s.35I) and access to computerized data to be given to the authorized officer (including necessary password, encryption code, decryption code, software or hardware) (s.35J). The authorized officer is also empowered to require the production of records, accounts, computerized data and documents kept by a contractor or other person; inspect, examine and download from them, make copies and extracts from them; require the production of identification document from any person; and make inquiry as may be necessary to ascertain compliance with the Act (s.35W).

With regards to the person who can exercise all the powers of enforcement, the Act provides for any police officer from Inspector rank and above as the authorized officer (s.35V).

\subsection{Entry into premise with and without search warranty}

For the carrying out of the power to enter into premise, where there is reasonable cause to suspect that there is article, thing, book, document, plant, substance and installation in the workplace which has been used to commit offence under the Act or Regulations, warrant may be obtained by DOSH from the Magistrate. The Magistrate shall issue a warrant, by which an officer named in the warrant may enter the workplace at any reasonable time day or night, and search for and seize or seal the article, thing, book, document, plant, substance and installation (s.40).

However, if the officer has reasonable grounds for believing that by reason of obtaining a search warrant, the said articles etc. in the workplace is likely to be removed or destroyed, the officer may enter without a warrant and seize or seal the article etc. found therein. If it is necessary, the officer may also break open door of workplace and enter; forcibly enter; remove by force any obstruction to entry, search, seizure and removal; and detain any person in the place until search completely carried out (s.42).

Similarly, under the CIDB Amendment Act, where there is reasonable cause to believe that any premise or construction site has been used to commit offence, the Magistrate may issue a warrant authorizing the authorized officer named therein, at any reasonable time by day or night to enter the premise or construction site and if need by force (s.35C).

If the authorized officer has reasonable cause to believe that by reason of delay in obtaining search warrant, the investigation would be adversely affected, the object of entry is likely to be frustrated, construction evidence may be removed/interfered with, or the evidence sought may be tampered with or destroyed, then the authorized officer may exercise his powers as if he were authorized to do so by a warrant (s.35D).

With the warrant, the authorized officer may also search and seize, take samples, make copies of or take extracts, and affix seal to the premise or construction site or any part thereof or anything therein. If necessary, the authorized officer may also break open door of the premises or construction site; remove by force any obstruction to entry, search, seizure and removal; and detain any person in the premise or construction site until the search completed.

The authorized officer shall also seal the construction material, equipment, instrument, book, record, document, computerized document, article or other thing in the premise or construction site in which it is found (s.35C). The additional power of CIDB includes the following:

\subsubsection{Sale and disposal of seized material}

The Act authorizes the Chairman of Lembaga to direct any construction material seized be sold and hold the proceeds while waiting for the prosecution result. This involve construction material which is of perishable nature and easily deteriorates in quality, the custody of it involves unreasonable expense and inconvenience, lack of proper facilities for the storage of it, or the material is believed to cause an obstruction or is hazardous to the public.

The material is also to be disposed if the analyst certifies that the material is not in good condition and no prosecution is instituted (s.35P). Further, the construction material or the proceeds of sale thereof, or any equipment, instrument, book, record, 
document, computerized document, article or other thing seized, shall be liable to forfeiture, and the forfeited material shall be the property of the Lembaga (s.35Q).

\subsubsection{Release of things seized}

The Act also permits the authorized officer to release the seized construction material or things to the person lawfully entitled to it if it is not required for purpose of any proceedings. Neither the authorized officer affects the seizure nor the Government, the Lembaga or any person acting on behalf, shall be liable to proceedings by any person if the seizure and the release had been affected in good faith (s.35R).

\subsubsection{Cost holding equipment etc. seized}

Where the construction material and things is held in the custody of the Government or the Lembaga, pending completion of court proceedings, the cost of holding in custody shall be a debt due to the Government, if the person found to have committed the offence (s.35S).

\subsection{Investigation by DOSH and CIDB}

As far as the power of investigation is concerned, officers of DOSH may exercise the special powers relating to police investigation, except the power to arrest without warrant under the Criminal Procedure Code. Once investigation completed, the officer shall give all information relating to the offence committed to the police station for the police officer by warrant, to arrest any person who may have committed the offence (s.44).

This power to carry out investigation is also given to the authorized officer under the CIDB Amendment Act. Once investigation completed, the authorized officer shall give all information relating to the offence committed to the police station for the police officer by warrant, arresting any person who may have committed the offence (s.35A).

During investigation, the authorized officer may require attendance of any person who is acquainted with the facts of the case. Refusal to attend, a Magistrate shall issue a summon to secure the attendance (s.35M). The authorized officer may also examine orally any person supposed to be acquainted with the facts of the case (s.35N).

\subsection{Inspection and obstruction provisions}

As such, during inspection, if the employer refuses the officer access to the workplace, obstructs the DOSH's officers in exercise of his powers, fails to produce document required by the officer, conceals the location or existence of person, plant or substance from the officer, prevents any person from assisting the officer, or hinders, impedes, opposes the officer from his duties, the offence shall be on conviction, be liable to a fine not exceeding RM10,000 or to imprisonment for a term not exceeding one year or to both (s.47).

Under the CIDB Amendment Act, a person would be liable to a fine not exceeding RM2,000 or to imprisonment for a term not exceeding six months or to both if convicted of the following offences:

a) Assaults, delays, impede, hinder or obstruct authorized officer in effecting any lawful entrance.

b)Breaks any seal affixed by authorized officer;

c) Fails to comply with lawful demand of authorized officer;

d)Fails, refuses or neglects to give information required by authorized officer; or

e)Fails to produce construction material and things required by authorized officer (s.35U).

\subsection{Appeal by aggrieved person}

Under the OSHA 1994, there is an appeal provision which stipulates that a person who is aggrieved by the notice issued may, within 30 days from the notice date, appeal to the Director General, who may confirm, revoke or vary the notice by order in writing. If the person is aggrieved with the decision of the DG, he may, within 30 days from the decision date, appeal to the appeal committee appointed by the Minister (s.50). However, there seem to be no appeal provision provided in the CIDB Amendment Act.

\subsection{Safety of building and construction works}

There is also a new Part VIIIA (Safety of Building and Construction Works) included in the CIDB Amendment Act 2011 that specifically imposes duties on contractors undertaking any construction works. The provision "shall ensure the safety of building and the construction works" means ensuring any building or construction works are carried out in a manner not causing or threatening to cause risk of injury to any person or property; or not causing or threatening to cause a total or partial collapse of the building and any other building, road or natural formation which is opposite, parallel, adjacent or in close proximity to any part of the building or construction works (section 34B(2)).

The effect of breach would be a penalty of not exceeding RM500,000 or issuance of written directives by the Lembaga to the contractor; for the contractor to immediately stop the works, to carry out inspection, to execute works as Lembaga may specify, to demolish the defective building and remove demolition debris (all these to be carried out at the contractor's cost); and the Lembaga may revoke or suspend registration of the contractor (section 34C (1)(2)).

While the directive is in force, the contractor must display a copy of it at every entrance to the building in a way that can easily be read by people outside the building (section 34C (5)).

Failure to comply with the directive means guilty of an offence and shall be liable to a fine not 
exceeding RM500,000, and in addition, any execution of the directive by the Lembaga itself, the Lembaga may recover from the contractor as a debt due, all expenses incurred by the Lembaga in doing so in a court proceeding (section 34C (3)(4)).

The contractor shall also pay or reimburse the expenses incurred by the Lembaga in engaging a qualified person or a specialist to carry out investigations and tests relating to safety of the building, failing which the amount shall be recoverable through a court proceeding (section $34 \mathrm{C}$ (7)). If the breach of the contractor of his duties resulted in death, he shall be guilty of an offence with a fine not exceeding RM500,000 or to imprisonment for a term not exceeding two years or both (section 34D).

\section{Conclusion}

From the above elaboration, the impact of the amendment to the Act shall make the contractors, in particular, have to prepare themselves to conform to the statute not only to ensure the safety of building, during and post construction works, but also to face safety and health enforcement from the respective agencies.

In addition, whether multiple charges arising out of the same conduct or multiple punishments for the same offence of the contractors can lead to issue of double jeopardy, is pertinent as it is prohibited, unless authorized by the legislature. Parliament might allocate overlapping jurisdiction, but give different policy tools to different agencies. Or both agencies may end up with duplicating duties and authority and the first thing to determine is which has more dominant power over the other.

In dealing with the concurrency of competences, it is suggested that where powers are dispensed between more than one levels of government, there are various means to be done. A dualist approach would seek to list each sphere's powers exhaustively. Another approach is to define one sphere's powers and leave the residual powers to the other. Another added technique is to give the same powers to both spheres in a form of concurrent list and further provide overriding clause in cases of conflict or disagreement (Steytler, 2011).

Thus, coordinated strategies and programs are needed, without which the uncoordinated overlapping jurisdictions can lead to conflicts or disagreements, inconsistencies and inaction, in management and in enforcement (Gersen, 2006).

\section{References}

Gersen JE (2006). Overlapping and underlapping jurisdiction in administrative law. The Supreme Court Review, 2006(1): 201-247.

MPC (2011). Opening Speech by Deputy Minister of International Trade and Industry, Conference on Modernising Business Regulation. Available online at: http://www.mpc.gov.my/wp-content/ uploads/2016/04/newsletter_Issues04.pdf

OECD (2013). Public Consultation on Best Practice Principles for Improving Regulatory Enforcement and Inspections. Available online at: http://www.oecd.org

Rozanah AR (2015). Managing safety at work issues in construction works in Malaysia: A proposal for legislative reform. Modern Applied Science, 9(13): 108-121.

Steytler N (2011). Defining provincial and local government powers and functions: The management of concurrency. Community Law Center, University of the Western Cape, Bellville, South Africa

Uhlmann DM (2008). Prosecuting worker endangerment: The need for stronger criminal penalties for violations of the occupational safety and health act. American Constitution Society for Law and Society, Forthcoming, University of Michigan Public Law Working Paper No. 120. Available online at: https://ssrn.com/abstract $=1262922$. 